Journal of Teaching English

Volume 4 No. 4, 2019

e-ISSN: 2548-6810

\title{
TEACHER'S STRATEGY IN DEALING WITH STUDENTS' MISBEHAVIOR IN SMPN 1 LASALEPA SUBDISTRICT OF MUNA REGENCY
}

\author{
Yuli Rahmawati ${ }^{1}$ Firdaus Sale $^{2}$ Lelly Suhartini ${ }^{3}$
}

${ }^{1}$ Halu Oleo University, Indonesia.

\begin{tabular}{l}
\multicolumn{1}{c}{ ARTICLE INFO } \\
\hline Keywords: \\
Students' \\
Misbehavior, \\
Teachers' Strategies, \\
Learning Process \\
How to cite: \\
DOI:
\end{tabular}

\begin{abstract}
This study aimed at knowing the types of students' misbehavior mostly happened in the learning process and strategy that teacher used in dealing with the students' misbehavior at the first and second grade in SMPN 1 Lasalepa. The researcher employed descriptive as the design of the study where observation was used to collect the data. The results of the study showed that the misbehavior of students mostly happened in the class were: talking during the class, lack of concentration, joking, laziness, daydreaming, disobedience and running about the class. Then, teachers' strategies used in dealing with the students' misbehavior were: asking the students calmly but strictly to stop the students' behavior problems, ignoring the students' misbehavior and not paying attention to it, walking toward the student and getting physically close to them, and giving students questions in the classroom. As the result, it is necessary to be known due to problems always come in the class and teachers need to know the kinds of the problem and need to prepare the appropriate strategies to handle the problems properly in order to not disturb the learning process.
\end{abstract}

\section{INTRODUCTION}

Teaching is a process of delivering knowledge, experiences, skills, attitudes, and moral values to the students. A teacher is the biggest noble of work for the educational system. As a guide, leader and core model in the class, teachers must show positive thing in front of the class because everything that teachers do in the class is becoming the example of students' behavior (Alma in Purwanti, 2015). A teacher has power in the class to control students' behavior and control the class 
activity by applying rules and procedures during the teaching process until the class end. It is helping teachers if something unwanted thing happened in the class. That is why teachers must control their behavior and show a good attitude in front of the students.

Teaching-learning process that teachers build in the class will work properly if teachers apply discipline in the class. Disciplines are rules, orders, arrangements, and systems to organize all activity in a school or in a classroom. Discipline arranges the teaching-learning process. Discipline can avoid problems and trouble that happen in the class. On the contrary, indiscipline cases caused the learning process will not run well because every problems, trouble or disruptions will come and damage the teaching-learning process (Gitome, Katola, \& Nyabwari, 2013).

In the teaching process, teachers must manage the students' behavior to maintain the classroom climate due to students' behavior influences in the teachinglearning process. Mulyadi (2009) points out the management of students' behavior influences the activity in the class, because students can study diligently and effectively if their behavior managed properly. Students' behavior truly influences the learning activity. If the behavior is in difficulties and teacher cannot manage it properly, so the learning process will not run well and the purpose of the study will not be reached. Students' behavior that cannot be managed properly refers to the problems, trouble, and disruptions that damage the teaching-learning process. It causes the emergency of disruptions to come frequently so that the teaching-learning process works ineffectively.

Students with a lot of behavior must be managed, controlled and arranged by a teacher in a classroom. It is really difficult to be finished well due to a person must manage a lot of students in a classroom with a lot of characters and a lot of behavior in a limited time. Due to students' behavior direct to the problems if it cannot be managed properly, so teachers must pay attention to that one. Teachers must know the students' misbehavior in order to identify easily, and also teachers must know 
the way of managing the students' misbehavior in order to make teachers solve the problems effectively.

The researcher conducted the research in SMPN 1 Lasalepa in which it is a junior high school where it is located in Bonea village, sub-province of Muna, Southeast Sulawesi. Based on the researcher's pre-observation, the researcher saw that the English teachers managed the students' behavior. Begin from teachers entered the classroom until teachers left the classroom, teachers could manage students' behavior and problems in the class. Therefore, controlling the students' misbehavior is truly needed in educational activity, and it becomes the reason for the researcher to know how that school especially English teachers in SMPN 1 Lasalepa manage their students' misbehavior.

\section{LITERATURE REVIEW}

\section{a. Concept of Strategy}

The strategy is a word that has many meanings in its' place based on the utilizing of the word, whether it is in business quality, organization scope, corporations' scope or in the educational world. Experts have differences concept or definition of the word "strategy" based on the place. However, strategy comes from Greek which is appearing as the concept of military connotation. A strategy was which in Greek means strategos. Strategos means as a general in command of troops or the art of general or plans to destroy enemies through effective use of resources (Mainardes, Ferreira \& Raposo, 2016).

The concept of strategy comes from the military and then adapted in the business area. Strategy in the military means that connecting the gap between two things that are separated. The strategy is needed to connect both things which can help the success of the military (Nickols, 2016). Generally, a strategy is a step, techniques or tactics which did by someone or a group to achieve the purposes they have planned (Pringgawidagda, 2002). The strategy helps someone or organizations reach purposes have been planned due to strategy is like a bridge to concentrate two 
separate things or more into one unity. Steiner (1997) points out the definition of strategy in the business world.

In the educational world, a strategy is truly important to manage class activity, including in managing the students' behavior. Teachers must have planning about strategies to be used in controlling the students' behavior. Positive students' behavior which direct to the good attitude was needed due to can create a good atmosphere in the classroom. It also helps teachers to manage the classroom situation to be consistent in the necessary environment. In this scope strategy also has the same definition that is way/steps, techniques, and tactics of the teacher to manage the students' behavior.

The biggest problem that teachers face as a leader in a class is managing the students' misbehavior. Teachers must think a lot to think about the strategies needed to solve the students' behavior problems. Not only disturbing another student, but also the problem that students make is disturbing and destroying the class activity, so that sometimes the purposes they have targeted cannot be reached well. That is why teachers must have strategies to manage the students' misbehavior. Ali, Abdullah and Majid (2014) state that various strategies that teachers can use in managing the students' behavior problems truly effective to control it. That is why the teachers must be aware of it.

\section{b. Concept of Students' Misbehavior}

The behavior of students always affects the class activity. When something strange comes to the students (related to the behavior) in the learning process, it would disturb the learning process. The teaching-learning activity will not run well and make the class becomes ineffective. These students' behavior called as the misbehavior of students which contravene the rules, disturb the classroom order and offend the teaching-learning activity (Sun \& Shek, 2012).

The classroom misbehavior varies based on the background of the country. Some countries have a different perception of classroom misbehavior. Sun \& Shek (2012) explained that in the United Kingdom and Australia, the misbehavior occurs Yuli Rahmawati: Teacher's Strategy in Dealing with Students' Misbehavior in SMPN 1 Lasalepa Subdistrict of Muna Regency 
when students bother the classroom order, make problems to the teacher and make some nonverbal noises. On the other hand, in the United States, students' misbehavior is happening when students do what the teachers prohibit to do and students do not do what the teacher asked to do. Instead, in China students who have many questions and always ask the teacher called as classroom misbehavior.

From the above explanation students' misbehavior vary across culture and country. The variety of the misbehavior cannot be handled from its culture, due to the culture is affecting the behavior of people in a country.

Sun and Shek (2012) defined the definition of students' misbehavior as the behavior of students that break the rules of the classroom, disrupt the norms of the class, disturb the classroom setting, and upsetting the teacher and students in the learning process. Wedhanti and Sasih (2017) explained that the misbehavior is behavior that happens in the classroom that can destroy the classroom climate and the teaching-learning activity, also restrain the achievement of the purposes of the study and bring it into the problems.

Problems or disruption happened in the classroom spend a lot of time for the teacher to manage the class. It relieves the time of teacher to conduct the teaching process, due to the disruption cannot be managed easily and have to take a long time to retain the appropriate atmosphere of the classroom. When problems come it causes the quality of the teaching becomes diminish, and it influences the process of getting the purposes of the study (Wedhanti \& Sasih, 2017).

Besides affecting the quality of the students, teacher, and school, the students' misbehavior also has negative effects of the school dropout, the students' ability in the school, and the teachers itself as the instructor in the school (Dalgic \& Bayhan, 2014). Those effects can influence the existence of the school in the educational world. If it cannot be handled properly, something trouble will come.

\section{c. Types of Students' Misbehavior}


Students' misbehavior is the behavior of students that happen in the classroom that can destroy the classroom climate and the teaching-learning activity, also restrain the achievement of the purposes of the study and bring it into the problems (Wedhanti \& Sasih, 2017). There are many types of students' misbehavior that happen in the classroom that always teachers confront every day and every time teachers enter the classroom to teach. Experts also have different perceptions of the problems or disruptions happen in the class according to class, lesson content, educational level, time and students' characteristics (Tsouloupas, Carson \& Matthews, 2014).

Below are several types of students' misbehavior according to several experts. Sun and Shek (2012) point out the students' misbehavior into several types such as:

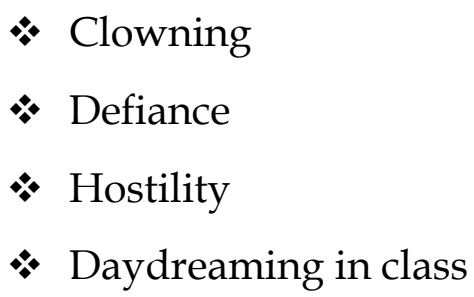

Meyers (2003) also points out the students' misbehavior that happen in the classroom such as:

* Talking during class

* Eating or drinking

* Sleeping during class

* Coming late

* Leaving class early

Al-Hassan (2002) and also mentions seven misbehavior that destroy the class activity such as:

\section{* Fighting}

* Running about the class

* Damaging class furniture 
Finn, Fish and Scott (2008) also reveal some students' misbehavior that happen in the class like:

* Disobedience

* Laziness

* Lack of concentration

* Joking

\section{d. Strategy to Deal with Students' Misbehavior}

Al Qahtani (2016) states that there are several discipline strategies that used by teachers in academic classroom to control the students' behavior problems such as:

1. Giving the students a first notice to remind him of the rules of breaching the classroom' discipline

2. Walking toward the student and getting physically close to him

3. Ignoring the misbehavior and not paying attention to it

4. Talking to the students individually at the end of learning process

5. Giving the student task in the classroom

6. Asking the students calmly but stricly to stop the misbehavior

7. Asking the student to leave the class if the behavior is repeated

8. Holding the student who is absent or arrives late accountable

9. Moving the student from one seat to another

\section{e. Previous Study}

Concerning the study of teachers' strategies in dealing with students' misbehavior, the researcher mentions two previous studies. The first study comes from Al-Qahtani (2016) entitled “The Undesirable Behavior of Students in Academic Classrooms, and the Discipline Strategies Used by Faculty Members to Control Such Behavior from the Perspective of the College of Education Students in King Saud University". The purpose of the research was to identify the undesirable students' behavior in academic classrooms, and the disciplinary, 
Preventive and therapeutic strategies will be used by faculty members to control those behavior from the perspective of the College of Education's students at King Saud University. The researcher of this study used questionnaire and it showed that students' undesirable behavior often occur were: cheating and plagiarism regarding homework and research, replying with a rude manner, using cell phones, side talking, and arriving late to lectures. Related to the result of strategies teacher applied in the class were: giving the first notice to the student to remind him or her of the discipline rules, and asking the student calmly but strictly to stop the undesirable behavior.

The second previous study comes from Sun and Shek (2012) entitled “Student Classroom Misbehavior: An Exploratory Study Based on Teacher's Perceptions". The purpose of this research was to examine the conceptions of junior secondary school students' misbehavior in the classroom and to identify the most common, disruptive, and unacceptable student problem behavior from the teachers' perspective. The researcher in this study used an interview to collect the data. The results of the study showed that the most common and disruptive problems behavior was talking out of turn, followed by inattentiveness, daydreaming, and idleness. The most unacceptable problems behavior was disrespecting teachers in terms of disobedience and rudeness, followed by talking out of turn and verbal aggression. The findings revealed that teachers perceived student problem behavior as those behavior involving rule breaking, violating the implicit norms or expectations, being inappropriate in the classroom settings and upsetting teaching and learning, which mainly required intervention from teachers.

\section{RESEARCH METHOD}

In this study, the researcher used descriptive method as the design of the research. The subject of this research was two English teachers who taught at the First and Second Grade students of SMPN 1 Lasalepa. The types of students' misbehavior and teachers' strategies in dealing with students' misbehavior in English teaching became the data of this research. The researcher used observation 
in collecting the data and used descriptive analysis to analyze the data by adopting the steps from Mile and Huberman.

\section{FINDINGS AND DISCUSSION}

The findings were discribed in charts. We can see the types of misbehavior and strategies that teacher used in dealing with the students' misbehavior.

\section{Chart 1. Diagram of Most Problem Happend in the Class}

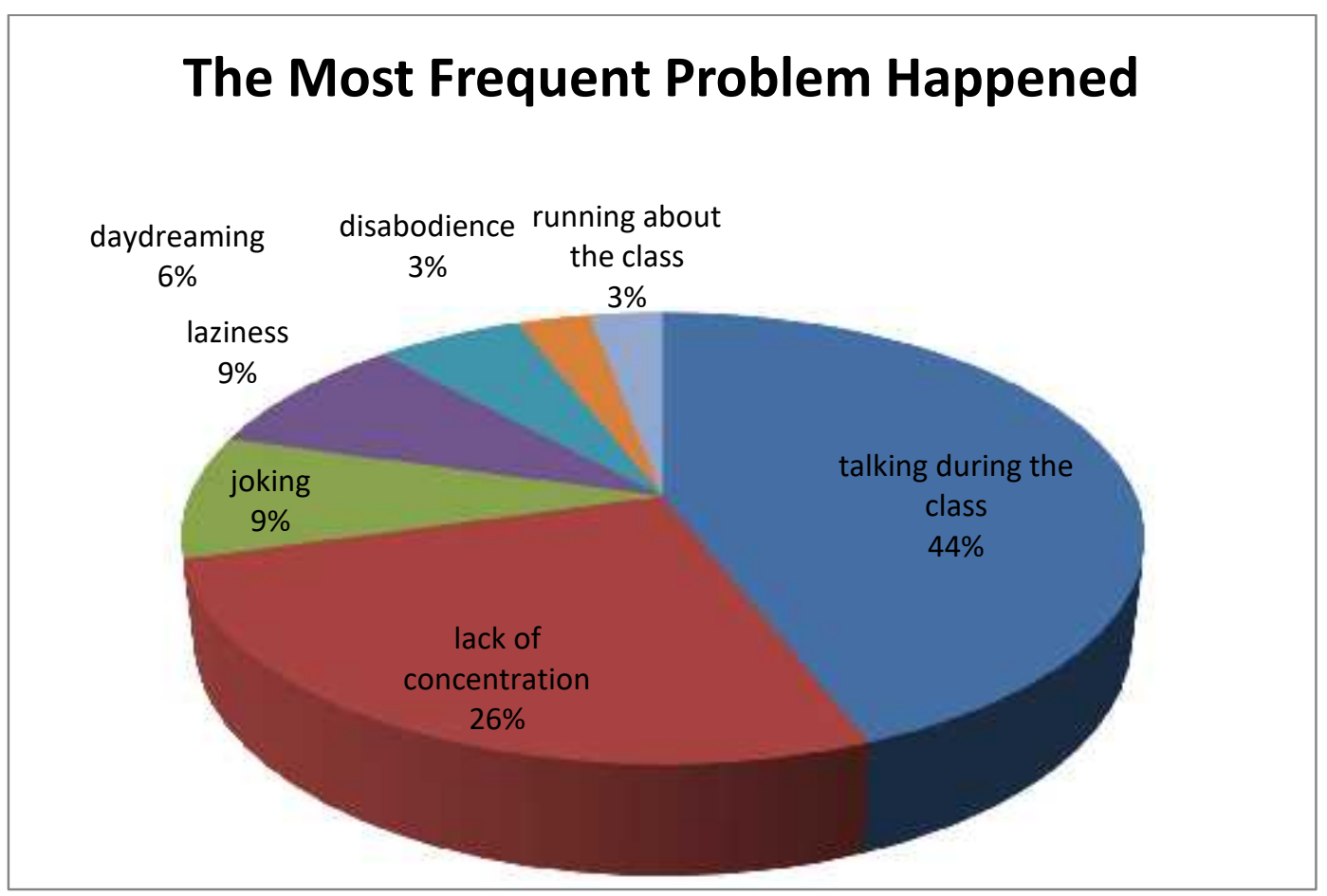

Based on the result of this research, the misbehavior of students that always came in every class in every observation is a percentage in the chart. The most misbehavior happened in the class in the class when the researcher did the observation in SMPN 1 Lasalepa is talking during the class and lack of concentration. Then joking, laziness, daydreaming, disobedience and running about the class were rarely happened in the class but quite disturbed the learning process. We can see the frequent of misbehavior happened in the class such as talking during the class $(44 \%)$, lack of concentration $(26 \%)$, then joking $(9 \%)$, laziness $(9 \%)$, daydreaming $(6 \%)$, disobedience $(3 \%)$ and then running about the class $(3 \%)$ that happened rarely. Sun and Shek (2012), Meyers (2003), Al-Hassan (2002), and Finn, 
Fish, and Scott (2008) revealed them as behavior problems happened in the class and disturbed the learning process.

\title{
Chart 2. Diagram of Teacher's Strategies in Dealing with Students'
}

\author{
Misbehavior
}

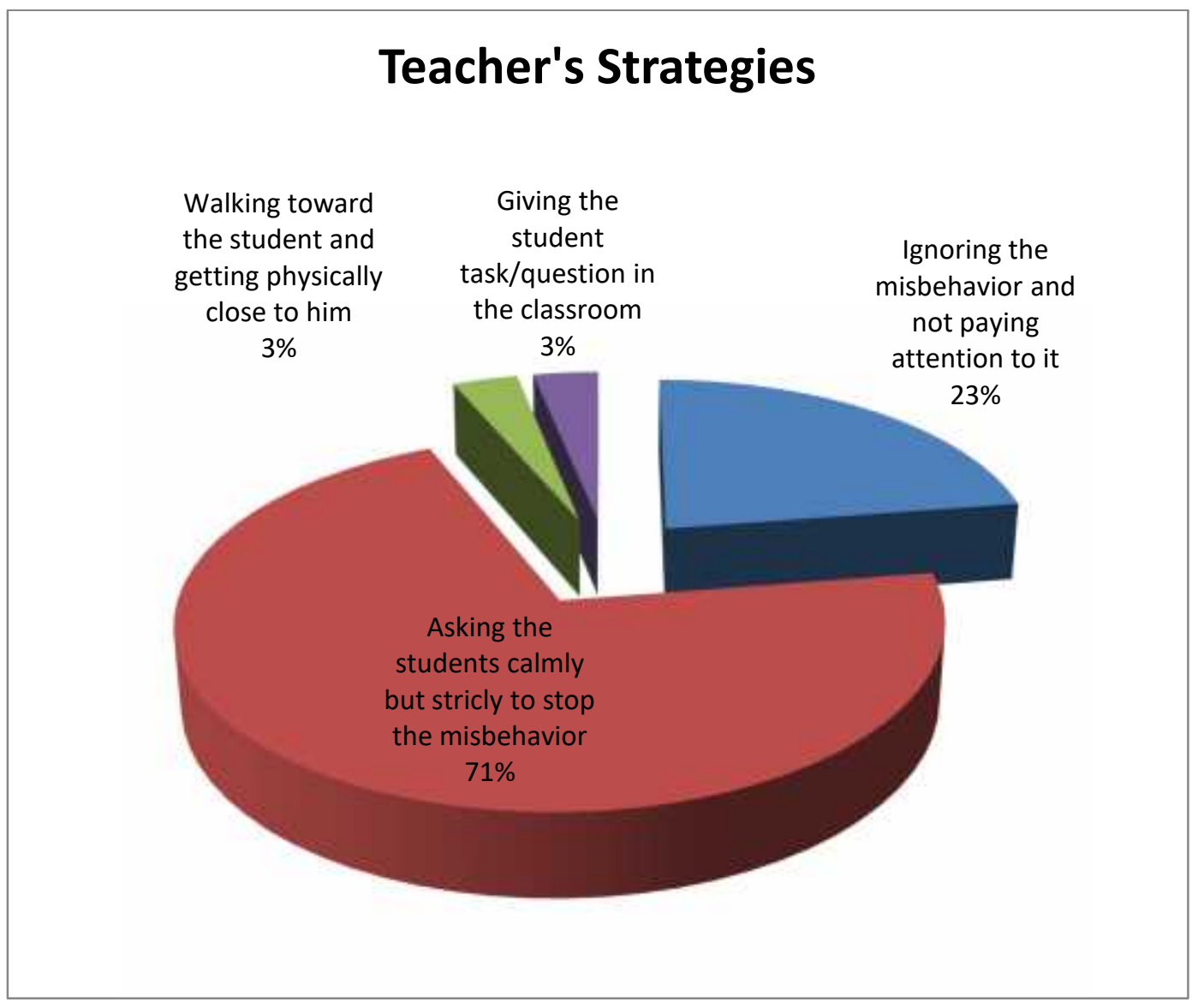

This chart showed the most strategies used by teachers in dealing with the students' misbehavior. The blue one is a strategy that teacher used namely asking the students calmly but strictly to stop the misbehavior of students $(71 \%)$, then ignoring and not paying attention to the misbehavior happened in the class $(23 \%)$. Meanwhile, walking toward the students and getting physically close to the students (3\%), and giving question to the students in the classroom (3\%) were rarely Yuli Rahmawati: Teacher's Strategy in Dealing with Students' Misbehavior in SMPN 1 Lasalepa Subdistrict of Muna Regency 
happened but it quite effective in solving the misbehavior. Al Qohtani (2016) revealed them as discipline strategies in dealing with the students' misbehavior.

\section{CONCLUSION}

Based on the findings of this research, the researcher concluded that there were seven problems happened in the learning process and it disturbed the learningteaching activity such as talking during the class, lack of concentration, joking, laziness, daydreaming, disobedience and running about the class. Then strategies that teacher used in dealing with the students' misbehavior were asking the student calmly but strictly to stop the student' misbehavior, ignoring the students' misbehavior and not pay attention to it, walking toward the student and getting physically close to him and giving the student task in the classroom.

\section{REFERENCES}

Ali, M.M., Abdullah, R., \& Majid, R. A. (2014). Teacher Trainees' Strategies for Managing the Behavior of Students with Special Needs. International Education Studies, Vol. 7, No. 13

Al Hassan, A.B. (2002). Teachers and their disruptive pupils. Zaria, Nigeria: Ahmadu Bello University.

Al Qahtani, N. S. S. (2016). The Undersirable Behavior of Students in Academic Classrooms, and the Discipline Strategies Used by Faculty Members to Control Such Behavior from the Perspective of the College of Education Students in King Saud University. International Education Studies, Vol. 9, No. 3

Cowley, Sue (2010). Panduan Manajemen Perilaku Siswa. Jakarta: Penerbit Erlangga Dalg1c, G. \& Bayhan, G. (2014). A Meta-Analysis: Student Misbehavior That Affect Classroom Management. Cypriot Journal of Educational Sciences, Vol. 9, No. 2.

Demir, S. (2009). Teacher perceptions of classroom management and problematic behavior in primary schools. Procedia - Social and Behavioral Sciences, Vol. 1, No. 1. doi:10.1016/J.Sbspro.2009.01.105

Finn, J.D., Fish, R.M., \& Scott, L.A. (2008). Educational sequelae of high school misbehavior. The Journal of Educational Research, Vol.101, No. 5.

Gitome, J.W., Katola, M. T., \& Nyabwari, B.G. (2013). Correlation Between Students' Discipline and Performance in the Kenya Certificate of Secondary Education. International Journal of Education and Research, Vol. 1, No. 8. 
Mainardes, E. W., Ferreira, J., \& Raposo, M. L. (2014). Strategy and Strategic Management Concepts: Are they recognized by Management Students? Research Gate, Vol. 17, No. 1.

Meyers, S. (2003). Strategies to prevent and reduce conflict in college classrooms. College Teaching, Vol. 51, No. 3.

Miles, M. B., \& Huberman, A. M. (1994). Qualitative Data Analysis. Sage: Thousand Oaks California.

Mulyadi (2009). Classroom Management. Malang: UIN-Malang Press.

Nickols, F. (2016). Strategy: Definition and Meaning. Retrieved from https://www.nickols.us/strategy_definitions.pdf

Postholm, M.B. (2013). Classroom Management: What Does Research Tells Us?. European Educational Research Journal EERJ, Vol. 12, No. 3.

Pringgawidagda, S. (2002). Strategi Penguasaan Berbahasa. Yogyakarta: Adicita Karya Nusa.

Purwanti, D. (2015). Manajemen Kelas di Kelas V Sekolah Dasar Negeri SeKecamatan Danurejan Yogyakarta. Unpublished thesis, Universitas Negeri Yogyakarta.

Steiner, G.A. (1997). Strategic Planning. What Every Manager Must Know. Canada: Free Press

Sun, R.C.F., \& Shek, D.T.L. (2012). Classroom Misbehavior in the Eyes of Students: A Qualitative Study. The scientific World Journal, Doi: 10.1100/2012/398482.

Sun, R.C.F., \& Shek, D.T.L. (2012). Student Classroom Misbehavior: An Exploratory Study Based on Teacher's Perceptions. The Scientific World Journal, Doi: 10.1100/2012/208907.

Tsouloupas, C.N., Carson, R.L., \& Matthews, R.A. (2014). Personal and school cultural factors associated with the perceptions of teachers' efficacy in handling student misbehavior. Psychology in the Schools, Vol. 51, No. 2.

Vijayan, P., Chakravarthi, S., \& Philips, J. A. (2016). The role of Teacher's Behavior and Strategies in Managing a Classroom Environment. International Journal of Social Science and Humanity, Vol. 6, No. 3.

Wedhanti, N. K., \& Sasih, L. L. (2017). An Analysis of Students' Classroom Misbehavior in Mechanical Engineering Departement Class of Grade XI in SMK Negeri 3 Singaraja. International Journal of Language and Literature, Vol. 1, No. 1.

Yuan, X. \& Che, L. (2012). How to Deal with Student Misbehavior in the Classroom? Journal of Education and Development Psychology, Vol. 2, No. 1. 
Journal of Teaching English Vol. 4 No. 4, 2019

Yuli Rahmawati: Teacher's Strategy in Dealing with Students' Misbehavior in SMPN 1 Lasalepa Subdistrict of Muna Regency 